\title{
Series
}

\section{空から見る日本の地すべり地形シリーズー36ー Aerial watching of landslides in Japan -36-}

\section{飛驒山脈北部・白馬大池火山・乗鞍岳山頂部に認められる重力性山体変形}

Gravitational deformation around Mt. Norikura-dake, Shirouma-Oike volcanoes, Hida Range (northern Japan Alps), central Japan

八木浩司 Hiroshi YAGI/山形大学 Yamagata University

井口隆 Takashi INOKUCHI／防災科学技術研究所 National Research Institute for Earth Science and Disaster Prevention

キーワード : 乗鞍岳, 白馬大池火山, 火山噴出物堆積面, 重力性山体変形

Key words : Mt. Norikura-dake, Shirouma-Oike volcanoes, lava surface, gravitational deformation

\section{1. 白馬大池周辺の地形・地質概観}

飛驒山脈（北アルプス）北部に位置する筸馬岳から三 国境を経てさらに北東の小蓮華山に至る主稜は，東〜南 東向き斜面が30度以上の急崖で，西〜北西向き斜面がや や緩やかな非対称山稜を形成している（図-1)。それと は対照的に，小蓮華山からさらに下った海抜高度 $2500 \mathrm{~m}$ 以下の稜線部には，開析の進まない緩やかな起伏の斜面 や，ドーム状の地形が分布している（図-1,2）。あるい は, 馬蹄形状の崖面基部前縁をドーム状の地形に閉塞さ れるようにして白馬大池（海抜約 $2370 \mathrm{~m}$ ：写真 -1 (口絵 -1)）や風吹大池（海抜約 $1370 \mathrm{~m}$ ）などの湖沼が分布す

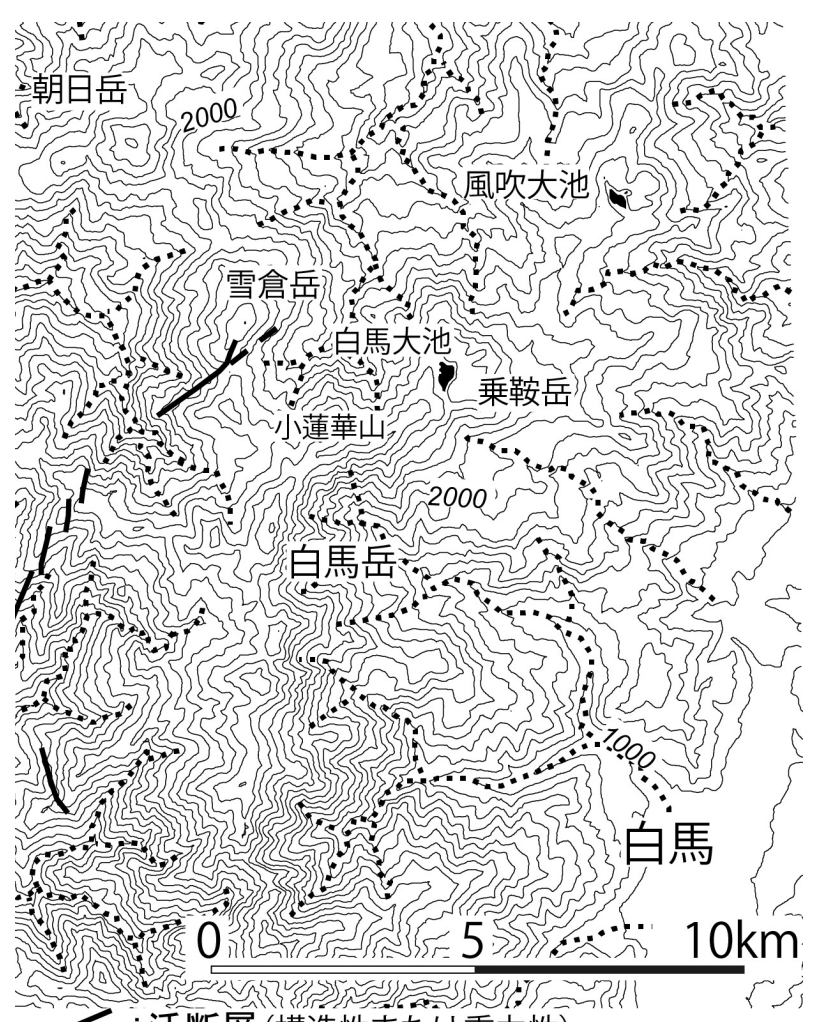

: 活断層(構造性または重力性)

$$
\begin{array}{ll}
\text { 図-1 } & \text { 飛驒山脈北部の地形概観 } \\
& \text { 等高線間隔は } 100 \mathrm{~m}
\end{array}
$$

る(図-1)。それらは, 白馬大池火山と総称され（中野 ほか, 2002), 第四紀中期以降の火山活動に伴って形成 された。上述の湖沼も，火山活動に伴って形成されたと 考えられている。

白馬大池の東に接する乗鞍岳（海抜 $2436.2 \mathrm{~m}$ ）も，約 17 万年前噴出の溶岩・灭砕岩で形成されている（及川ほ か，2001; 中野ほか，2002）。また乗鞍岳南面は，栂池 側に落ち达む比高 $500 \mathrm{~m}$ 以上の急崖を成しながら，緩や かな頭部に大きな荷重を残す釣り鐘状の形態を呈してい る(図-2)。

\section{2. 白馬大池火山・乗鞍岳の重力性山体変形}

乗鞍岳㧍よびその北側の独立標高点 $2469 \mathrm{~m}$ は, 一連の 乗鞍岳溶岩で形成されている（中野ほか，2002）。しか し, 乗鞍岳溶岩堆積面は, 並走する北東一南西走向の急 崖（図 2 : 崖面 $\left.\mathrm{A}-\mathrm{A}^{\prime}, \mathrm{B}-\mathrm{B}^{\prime}\right)$ にっって, 連続性が断ち

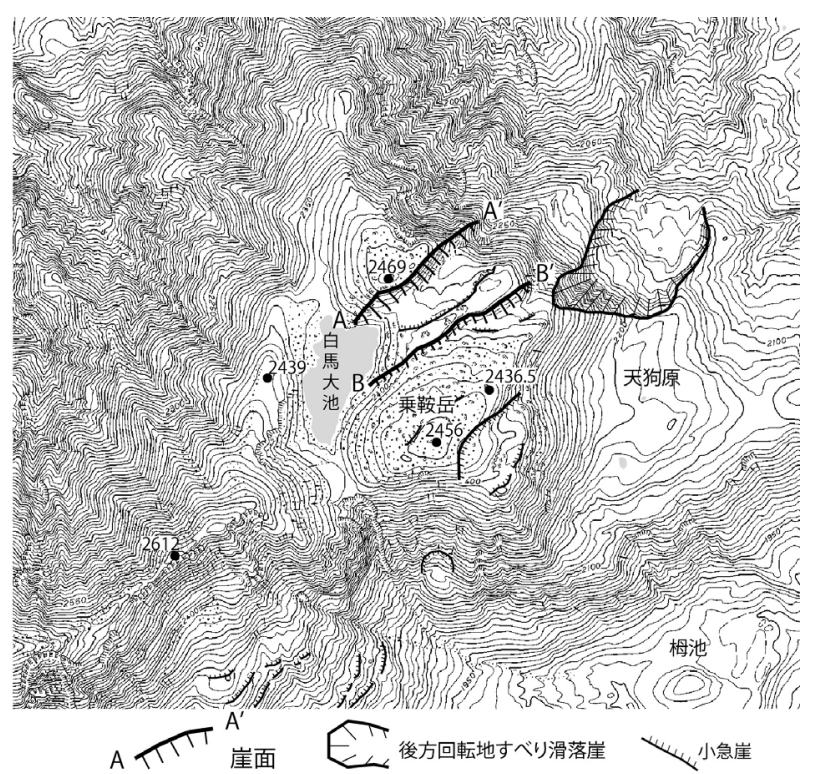

図－２白馬大池・乗鞍岳周辺に認められる重力性山体変位 地形 


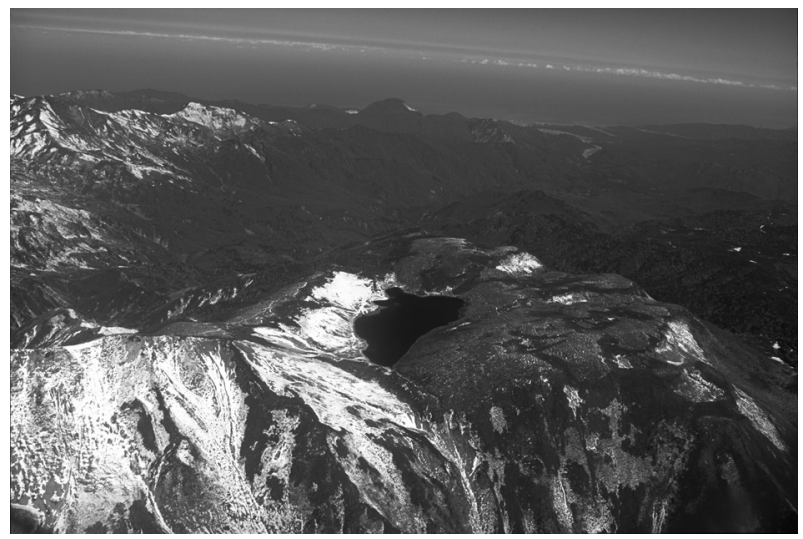

写真一 1 南方上空から見た白馬大池と乗鞍岳溶岩（2003年 10月撮影)

画面中央の水面が白馬大池，その右側の平坦面 が乗鞍岳溶岩の堆積面

切られ，大きくは 3 つの斜面に分断されている（口絵一 $2,3$ およ゙写真 $-2,3)$ 。崖面 $\mathrm{A}-\mathrm{A}^{\prime} ， \mathrm{~B}-\mathrm{B}^{\prime}$ は，いずれも $750 \mathrm{~m}$ 程度の長さで，比高は，地形図の読図からそれぞ れ最大 $50 \mathrm{~m}$ おび $20 \mathrm{~m}$ 程度である。侵食を考慮する必要 もあるが，崖面の比高は西から東側に大きくなる。また， 崖面AおよびBの西方延長部で，白馬大池西側の稜線に 高度的变化は現れていない。空中写真判読 $($ 写真 -4$)$ か らも一連の溶岩堆積面が，独立標高点 $2469 \mathrm{~m}$ の載る斜面 に対して，その南側が崖面 $\mathrm{A}-\mathrm{A}^{\prime}, \mathrm{B}-\mathrm{B}^{\prime} に$ 沿って，そ れぞれ北側にやや傾きながら階段状に沈下していること が確認出来る。このため，崖面 $\mathrm{A}-\mathrm{A}^{\prime} ， \mathrm{~B}-\mathrm{B}^{\prime}$ は，シー 卜状に地表を覆う乗鞍溶岩を，局地的な重力性断層が変 位させたものと考えられる。すなわち，乗鞍岳は，後方 回転運動を伴いながら，南側（栂池側）に押し出され変 位が進んだことが想定できる。さらに崖面 $\mathrm{A}-\mathrm{A}^{\prime}, \mathrm{B}$ $\mathrm{B}^{\prime}$ に沿った乗鞍溶岩堆積面の変位を戻せば，溶岩噴出当 時は，一連の溶岩ドームを形成していたことを示唆して いる。つまり白馬大池も，乗鞍岳溶岩の南側への移動に よって拡大したものと考えられる。

なお，乗鞍岳溶岩堆積面南東端は，さらに比高 $30 \mathrm{~m}$ 程 度の滑落崖を発達させながら，栂池側に地すべり変位を 起こしている。また，崖面 $\mathrm{A}-\mathrm{A}^{\prime} ， \mathrm{~B}-\mathrm{B}^{\prime} に$ 囲まれた斜 面上には，比高 $5 \sim 10 \mathrm{~m}$ の崖面 $\mathrm{A}-\mathrm{A}^{\prime} に$ 相対する北東一 南西走向の小急崖が発達している (図 - 2 )。乗鞍岳山 頂の北側にも同様な小急崖が認められる。それらは，崖 面 $\mathrm{A}-\mathrm{A}^{\prime}, \mathrm{B}-\mathrm{B}^{\prime}$ 形成時に二次的に形成された重力性山 体変形と考えられる。

乗鞍岳と小蓮華山に挟まれた南東向き斜面には，逆向 き小崖や線状凹地が数列発達している（図－2）。しか しそれらの規模は乗鞍岳山頂部の断層崖に較べ小さい。 これは，前者が層相変化の激しい古生代の混合岩類分布 地域で，地質構造に規制されながら発生していることに 対し，後者は乗鞍溶岩が厚く空間的にも広く分布する地 域で発生していることに起因するものと考えられる。

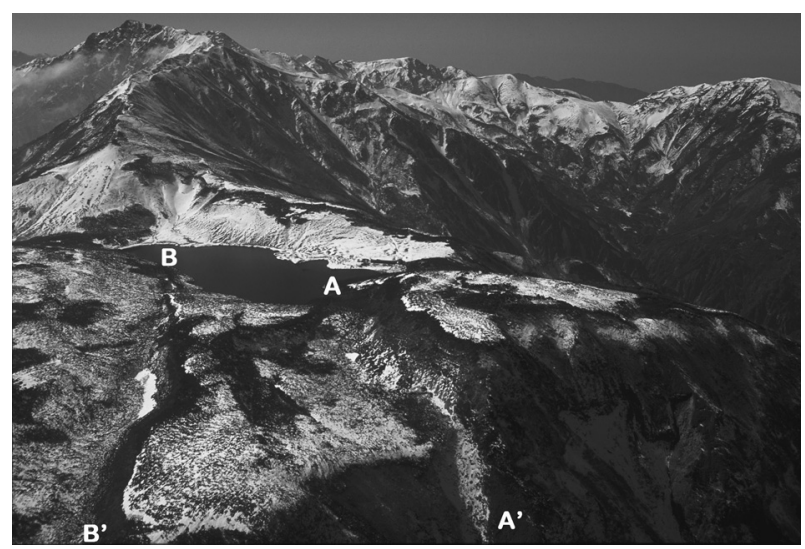

写真一 2 白馬大池・乗鞍岳溶岩堆積面を切る崖地形と飛驒 山脈北部主稜（1996年10月撮影）

白馬大池を東方から望む. 画面奧のスカイライ ンを呈する稜線が飛驒山脈北部主稜. 左奥のピー ク（三国境）から小蓮華山そして白馬大池に下る 山稜が見える.

AーA'およびB一B'を結んだ線に沿って崖面が 発達する。

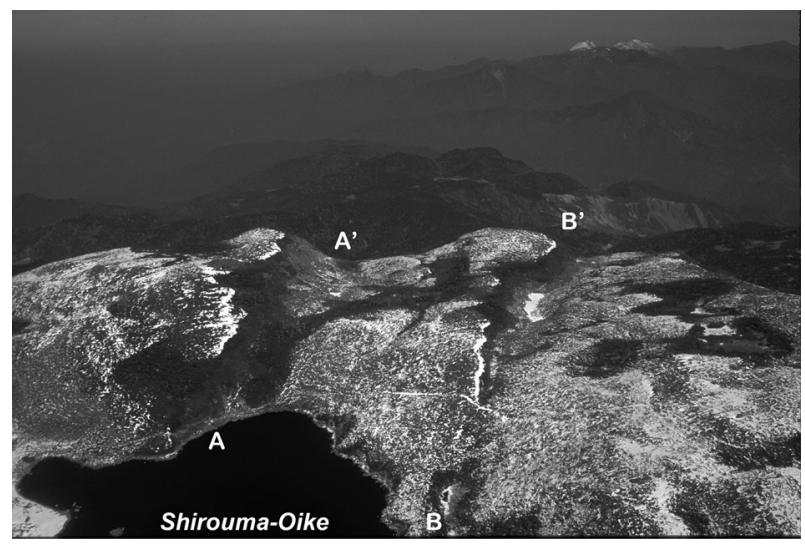

写真一 3 白馬大池・乗鞍岳溶岩堆積面を切る崖地形（1996 年10月撮影）白馬大池西上空から東方向を望む. AーA'およびB一B'を結んだ線に沿って崖面が発 達する.

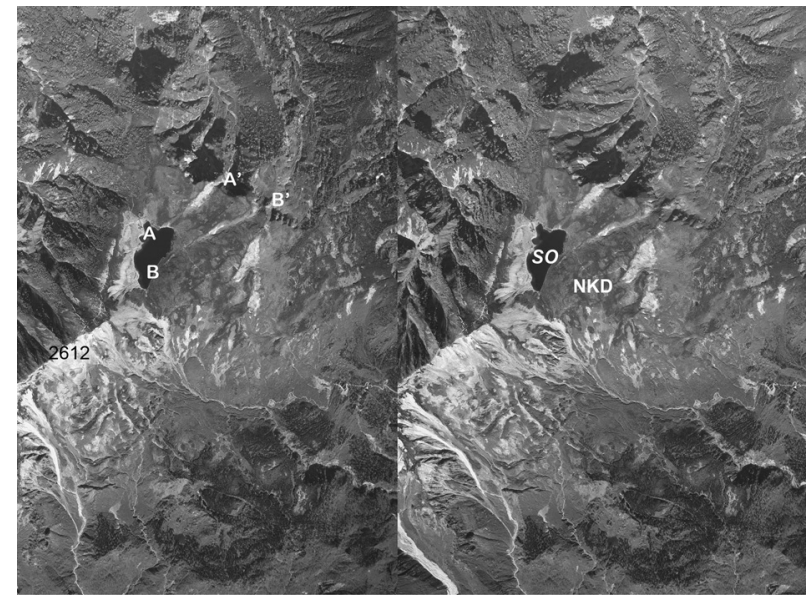

写真一 4 白馬大池及びその周辺の空中写真（実体視可） 国土地理院発行1/2万空中写真CB-2000-10Y C12,13

AーA'およびB一B'を結んだ線に沿って崖面が発 達する.

SO：白馬大池, NKD：乗鞍岳 


\section{引用文献}

中野俊 - 竹内誠 - 吉川敏之 - 長森英明 - 苅谷愛彦 - 奥村晃司 - 田 口勇作 (2002) : 白馬岳地域の地質. 地域地質研究報告 ( 5 万分 の 1 図幅). 産総研地質調査総合センター, 105p.
及川輝樹 - 原山智 - 梅田浩司 (2001) 白馬大池火山の $\mathrm{K}-\mathrm{Ar}$ 年代. 火山, 46, pp. 21-25. （原稿受付2014年 6 月25日，原稿受理2014年 6 月30日） 